2019 (113): 145-164.

(c) A szerző(k) 2019

replika.hu/replika/113

\title{
Пlészáros 〔saba
}

\section{Hié az antropocén?}

A globálıs klímaváltozás antropológıa szemlélete

\begin{abstract}
Absztrakt: A kulturális antropológia és a néprajztudomány már elnevezésében is azt sugallja, hogy az embert, az emberek csoportjait kutatja. Mindazt tehát, ami kulturális/társadalmi jelenség; a természet pedig e nézet szerint mindaz, ami nem kulturálisan, társadalmilag megteremtett, hanem már korábban, attól függetlenül is létező. Azokkal az elképzelésekkel vitázva, amelyek a bölcsészet- és társadalomtudományok szerepét másodlagosnak ítélik a technikai és természettudományos kutatásokkal és megoldási javaslatokkal szemben, az elmúlt két évtized antropológiai és/vagy filozófia eszmecseréi felvázoltak több olyan releváns értelmezési keretet, amely a társadalomtudományokat a globális klímaváltozásra adandó válasz megfogalmazásában nem a természettudományok kiszolgálójaként, követőjeként írta le, hanem autonóm, kezdeményező és innovatív tényezőként. A tanulmány saját terepmunka élményekre és az ontológiai antropológiai kutatásokban kiérlelt tapasztalatokra támaszkodva kívánja mérlegre tenni az antropológia lehetőségeit és a nyugati tudományosság fogalmi apparátusának érvényességét a klímaváltozásra adandó morálisan elfogadható válaszok kimunkálásában.
\end{abstract}

Kulcsszavak: antropocén, globális klímaváltozás, ontológiai antropológia, animizmus, Szibéria, ökológiai antropológia, permafroszt 


\section{Bajban vagyunk}

Minden kétséget kizáróan bajban vagyunk. Mégpedig olyan mértékủ és jellegű bajban, amelyet nem lehet és nem is tudunk megoldani. Nyilvánvalóan csak egyet tehetünk, megpróbálunk együtt élni vele (Haraway 2016). Ugyan vannak olyan hangok, amelyek a globális ökológiai változások jelentőségét és mértékét lebecsülik (vö. Lipschutz és Stabinsky 2019), azonban globális és lokális adatok sokasága támasztja alá azt, hogy egyre fogy az időnk (Marohasy 2017). A kortárs természet- és társadalomtudományi kutatások olyan, korábban nem tapasztalt klimatikus, hidrológiai, ökológiai jelenségeket és adaptációs folyamatokat tártak fel az elmúlt évtizedben az arktikus területektől egészen a trópusokig, amelyek az emberi és nem emberi közösségek életét radikálisan megváltoztatták. Emiatt ma már a morálisan elfogadható, és tudományosan megalapozott kérdés nem az, hogy bajban vagyunk-e - hanem az, hogy miképpen éljünk együtt ezzel a helyzettel, mekkora a baj mértéke, valamint az, hogy mindez milyen tennivalókat ró ránk, emberekre, és még szorosabban ránk, kutatókra (Pratt 2017: 170-171). A klímaváltozás okozta ökológiai változások erkölcsi kérdések sokaságát vetik fel mind az egyes társadalmakra, mind a nem emberi entitásokra vonatkozóan (Caney és Bell 2011). Ezek közül a jelen kulturális antropológiai esettanulmány elsőként a peremhelyzetű közösségeknek az élőhelyhez, életmódhoz való jogának kérdéseit veti fel, illetve közvetve azt, hogy az emberi tevékenység vajon milyen mértékben károsíthat vagy szüntethet meg egy-egy ökotopot. Közvetve azonban amellett kívánok érvelni, hogy antropológiai esettanulmányok által lehet és érdemes is finomítani azon a fogalmi készleten, amellyel a tudományos érdeklődés megragadni kívánja a jelen ökológiai kihívásait.

Azokkal az elképzelésekkel vitázva, amelyek a bölcsészet- és társadalomtudományok szerepét másodlagosnak ítélik a technikai, tudományos kutatásokkal és megoldási javaslatokkal szemben (Stilgoe 2015), az elmúlt két évtized kulturális antropológiai és/vagy filozófiai eszmecseréi felvázoltak több olyan releváns értelmezési keretet, amely a társadalomtudományokat a globális klímaváltozásra adandó válasz megfogalmazásában nem a természettudományok kiszolgálójaként, követőjeként írta le, hanem autonóm és innovatív tényezőként (Latour 2013). E fordulatra már csak azért is szükség mutatkozik, mert a társadalomtudományok eddig lényegesen kisebb szerepet vállaltak a jelen ökológiai problémáinak az értelmezésében, mint a természettudományok.

Önmagában már a tény is, hogy az antropocén fogalmát (amely terminus felvetése és népszerüsítése egy amerikai hidrológushoz, Eugene F. Stoermerhez és később egy holland Nobel-díjas légkörkémikushoz, Paul Jozef Crutzenhez köthető) a társadalomtudományok a természettudományos diskurzusokból vették át, követve az ott bekövetkezett paradigmaváltást (Crutzen és Stoermer 2000), arra utal, hogy a fogalom társadalomtudományi szempontból további megvilágítást igényel. Ezt az igényt mi sem támasztja alá jobban, minthogy az új földtörténeti éra leírására egyre több egymással versengő, egymást kiegészítő kifejezés született az utóbbi években: kapitalocén (Moore 2016), plantationocene vagy éppen a chthulucene (Haraway 2015). A kifejezések sokasága és az általuk beemelt új szempontok éppen arra mutatnak rá, hogy az antropocén fogalma - annak ellenére, hogy a koncepció megfelelő értelmezése, interiorizálása korunk egyik legjelentősebb kihívása és a modernitás végső meghaladásának egyik eszköze (Latour 2013: 144) - még mindig nem kellőképpen reflektált. 
A kulturális antropológiai szemlélet és az általa közvetített tereptapasztalatok elsősorban két szempontból járulhatnak hozzá a globális ökológiai és klimatikus változásokat mérlegre tevő diskurzusokhoz. Egyrészt esettanulmányok segítségével az alkalmazkodás sikeres és sikertelen példáit bemutatva, kiemelve a reziliens és a kevésbé ellenálló közösségek működésének sajátosságait; másrészt betekintést adva olyan gondolkodásmódokba, kategóriarendszerekbe (és egyúttal világokba is), amelyekben az egyes közösségek nemcsak emberekből állnak, hanem olyan más élő és élettelen entitásokból is, amelyeket az európai gondolkodás rendszerint a természet részének tekint. E világok és az e világokban kialakult viselkedésminták és ismeretelméleti rendszerek, mint pl. az erdei gondolkodás (sylvanian thinking Kohn 2013: 227), arra világíthatnak rá, hogy van mód radikálisan új morális tartással és igénnyel fordulni a környezetünkhöz.

Amikor tehát az antropocén éra kérdéseit és kihívásait az antropológiai kutatás mérlegre teszi, nemcsak egyfajta „kis színesként” kíván beemelni a közös diskurzustérbe egy-egy egzotikus példát annak érdekében, hogy azokból általános érvényü következtetéseket vonjon le (vö. Sivado 2015: 83-84). Éppen ellenkezőleg, alternatívákat, lehetséges kiutakat próbál kínálni, illetve kizárni olyan szociológiai, gazdasági és ökológiai következtetéseket, amelyek nem müköd(het)nek, vagy amelyek morális szempontból kétesek. A következő oldalakon egy olyan értelmezési keretet kívánok felvázolni, amellyel, meggyőződésem szerint, az antropológiai diskurzusok hatékonyan tudnak hozzájárulni az antropocénról, illetve a globális ökológiai változásokról szóló kortárs eszmecserékhez. Teszem mindezt azzal a céllal is, hogy elérhetőbbé tegyek egy Magyarországon kevésbé reflektált kulturális antropológiai szemléletet a hazai néprajzkutatás, illetve közvetve az antropológiai érdeklődésü társadalomtudományok számára.

E célnak megfelelően a tanulmány kettős igénnyel íródott; egyrészt terepmunkám tapasztalataira támaszkodva rövid leírást kíván adni arról, hogy miért és miképpen hordoz más üzenetet a globális klímaváltozás egy északkelet-szibériai közösségen belül, mint a nyugati és egyúttal tudományos gondolkodás számára. Másrészt javaslatokat kívánok megfogalmazni arra vonatkozóan, hogy miképpen lenne érdemes bedolgozni a terepmunka-tapasztalatokat és az antropológiai szemléletet azokba az eszmecserékbe, amelyek a globális klímaváltozás, illetve az antropocén korszak pontosabb megértését szolgálják.

\section{Természet és társadalom kettőssége - és e kettősség következményei}

Bajban vagyunk. És e bajnak a gyökere nem egyszerűen a pazarló emberi fogyasztásban, a népességszám meredek növekedésében, a fosszilis energiahordozók tékozló felhasználásában vagy éppen a környezetszennyezésben keresendő. Ezek a jelenségek valójában mind annak a világképnek az okozatai, amely Európában fokozatosan megszilárdulva, majd a modernitás korában kiteljesedve az embert és az emberi szférát kiemelte és egyúttal el is különítette az egyéb élő és élettelen entitásoktól - létrehozva természet és társadalom kettősségét (Descola 2013: 45). E kettősség egyaránt hatott az emberi társadalom és a számára erőforrásokat kínáló természet viszonyára, valamint arra, hogy miképpen különültek el egymástól egyre határozottabban és kölcsönösen a természet- és társadalomtudományok a 17. századtól kezdve (Dijksterhuis 2012: 73). 
E ponton joggal merül fel a kérdés, hogy milyen értelemben lehet gyümölcsöző valamiféle egységes európai és/vagy tudományos világképet feltételezni, és egyfajta kontrasztív hátteret felmutatni azokkal a helyi kategóriarendszerekkel szemben, amelyeket a továbbiakban szeretnék bemutatni. Különösen annak fényében kíván további magyarázatot ez az első látásra leegyszerüsítő megközelítés, hogy az antropológiai szakirodalomnak azon területén, amely határozottan épít e különbségtételre (jelesül az ontológiai antropológia) is, számos kérdést vet fel a nyugati/európai és nem nyugati/őshonos közötti különbségtétel (Candea 2011). Eza kontrasztív megközelítésmód mindazonáltal olyannyira általános az exoantropológiában, vagy ódivatúan hivatkozva rá a Völkerkunde, etnológiai jellegü kutatásokban, hogy sok esetben a legfontosabb kortárs kézikönyvek is további magyarázatra nem szoruló adottságként kezelik (Ingold 2018). Ugyan vannak olyan antropológiai törekvések, amelyek azt a célt tüzik ki, hogy rendszerszerűen és definitíven számba vegyék a nyugati/európai és egyúttal tudományos gondolkodás közötti hasonlóságokat és különbségeket (Horton 1993), ezek azonban óhatatlanul valamiféle esszencializmus áldozatai lesznek.

Van-e tehát értelme annak a heurisztikus antropológiai eljárásnak, amely módszertani eszközként mégis tételez valamiféle különbséget (más társadalmakkal szemben) és egységességet (önmagában) az európai gondolkodásban. E kettő ugyanis az a párban álló premissza, amelyekre az exoticizáció és a homogenizáció vádjával reagálnak a társtudományok az antropológiai munkák interpretációja során (Blaser 2013). Mario Blaser válasza szerint a nyugatiság nem egy egységes csoportot határoz meg, hanem inkább gyakorlatok sokaságát, amelyek ugyan (mint a gyakorlatok általában) nem hoznak létre koherens rendszereket, azonban tételezhető mögöttük egy olyan egységes szemlélet, világkép, amely a modernizmus episztemológiájában gyökerezik.

Ezen ismeretelmélet legalábbis két nagy elkülönítésen alapul: egyrészt a természet és a társadalom különválasztásán, másrészt a tudományos megismerés gondolatiságával átitatott és az ahhoz képest (legalábbis részben) önálló közösségek közötti különbségtételen. A „Nyugat” és a "mások” e szemlélet szerinti értelmezése magában hordozza azt a célkitüzést is, hogy az antropológus feladata nemcsak a mi és a mások, hanem a természettudományos és társadalomtudományos szemléletek közötti közvetítés is (Ingold 1993). Röviden, a címke, miszerint létezik egyfajta nyugati/európai/tudományos szemlélet és világkép (illetve egy vagy több vele szembeállítható más), nyilvánvaló módon leegyszerűsít, és heurisztikus céllal elhatárol egy sereg olyan gyakorlatot, amely a modernizmus ismeretelméletének sajátja, és amely az antropológiai megismerést és a tudományos gondolkodást jelentős mértékben meghatározta (Chandler és Reid 2018).

A modernizmus ismeretelméletében - és ennek következtében a nyugati társadalmak gyakorlatában - e két megkülönböztetés oly mértékben általános, hogy magát a kutatást is egyre növekvő mértékben meghatározta, és a természet, illetőleg a társadalom kutatását egyre inkább eltérő módszerek, ismeretelméleti keretek és érdeklődési körök területére szorította. A társadalomtudományok célkeresztjébe az ember, a kultúra és a társadalom jelenségei kerültek, a kutatók pedig olyan kérdéseket tettek fel, amelyeket e halmazon belül értelmezni lehetett. Vagyis a társadalomtudományokban az a kérdés, hogy mi a természet, mi a medve, a búza vagy éppen mi a tó, elsősorban olyan formában merült fel, hogy ezek az entitások kulturálisan/társadalmilag miképpen értelmeződtek, konstruálódtak, és hogyan álltak 
kapcsolatban az emberrel. A természet pedig mindazzá vált, amely nem tartozik az emberi szférába (Kohn 2015: 315). Amennyiben ezt a felosztást elfogadjuk, akkor kérdésként merül fel az, hogy egyáltalán miképpen ragadhatja meg a globális klímaváltozás jelenségkörét egy szociokulturális antropológus.

Ha ugyanis egyfajta dualitásként értelmezzük az ember és az ő nem emberi környezetének a viszonyát, könnyen arra a következtetésre juthatunk, hogy egyes jelenségek mintegy interfészként müködnek a társadalom és a természet között. Az egyik jellemzően ilyennek tekintett jelenség például a „táj”, amely nemcsak a rátekintő ember értelmezésétől nyer határokat, hanem azáltal is, hogy annak kialakításában az emberi ágencia szerepe a természeti erők mellett megkérdőjelezhetetlen. A két szféra érintkezésében a néprajztudomány és az antropológia hagyományosan az emberi tevékenységet tekintette aktívnak, a természeti környezetet pedig passzívan ellenálló vagy lassan reagáló, alig észlelhetően változó közegként értelmezte. E nézet szerint a természeti háttér előtt zajlanak le az attól eltérő szabályoknak engedelmeskedő társadalmi, kulturális folyamatok (Degler 1989). Bár a két szféra egymással érintkezhet, ám alapvetően különnemüek, és egymástól, ha másként nem is, kategoriálisan elkülöníthetők.

A természet és a kultúra különálló értelmezésére az egyik legjobb példát tudományágunk máig talán legjelentősebb vállalkozása, az óriási területet (a Csendes-óceán teljes északi peremét) felölelő Jesup-expedíció hozza (Vakhtin 2001). Az 1897 és 1902 között lezajlott kutatás fő szervezője és irányítója Franz Boas volt - az antropológiai szemlélet és kutatási módszertan egyik nagy hatású alakja. Boas az emberi kultúrák összefüggéseit, genetikus kapcsolatait feltárni kívánó kutatásait egy változatlannak tekintett földrajzi környezetbe helyezve képzelte el. A földrajzi viszony nála egyet jelentett a természetinek tekintett entitások elhelyezkedésével. Az eredetileg geográfusnak tanuló Boas Alfred Kroeber kritikájára adott válaszában úgy érvelt, hogy a kultúrák földrajzi meghatározottsága túlzott figyelmet kap (Boas 1936: 137). A természet és a kultúra markáns elhatárolása nemcsak a környezet anakronisztikus szemléletéhez vezetett el, hanem a kutató által természeti népeknek nevezett közösségek időtlen szemléletéhez is. A néprajzi/antropológiai kutatások ugyanis hajlamosak voltak a változó európai kultúrától elkülönített, a történelem egy pontján „megrekedt” kultúrákat a történetiség mellőzésével egyfajta anakronisztikus „etnográfiai időben” szemlélni (Fabian 2002: 25-35). Amint azt a későbbiekben látni fogjuk, éppen e „természetinek” tekintett közösségek vizsgálata mutatott rá arra, hogy nemcsak az antropológia időszemlélete vet fel jogos kritikákat, hanem annak ontológiája is.

Valójában nem megszüntették, hanem még inkább megerősítették a natúra és a kultúra elhatárolását azok az ökológiai antropológiai kutatások, amelyek nem kizárólag az emberi szférát kívánták vizsgálni. Julian Steward kutatásait követően (Steward 1955) az antropológia egyre inkább a környezetébe belehelyezett, azzal komplex kapcsolatban álló entitásként értelmezi az embert. A kultúra és a természet e megközelítésben két különnemü, de egymásra hatni képes szférát alkot; a közöttük lévő érintkezés sajátos eseteit pedig csak a kulturális jelenségek és társadalmak vizsgálatának tapasztalatával felvértezett, de ökológiai ismeretekkel is rendelkező sokoldalú kutatók képesek feltárni. Vagyis a néprajzkutatók és antropológusok egyre inkább bevonják az értelmezésbe a természettudományos szempontokat (Borsos 2017: 31-32). 
Ez egyúttal azt is jelenti, hogy van egy folyamatosan kiteljesedö, egyre alaposabb ismereteket továbbító természettudományi háttér, amelynek értelmezésében, kiszolgálásában segítenek az egyes kultúrák, világnézetek és gyakorlatok leírásai - vagyis az (ökológiai) antropológiai vizsgálatok. E megközelítés már Émile Durkheim 1912-ben írott, A vallási élet elemi formái címü munkájában is megjelenik:

Csak akkor lehetett azt mondani bizonyos tényekről, hogy természetfölöttiek, amikor már megvolt az az érzésünk, hogy a dolgoknak van egy természetes rendjük, vagyis hogy a világ jelenségeit szükségszerü kapcsolatok, úgynevezett törvények kötik egymáshoz. Ennek az elvnek a fényében aztán minden, ami áthágta e törvényeket, óhatatlanul mint a természeten, következésképp az értelmen kívül álló dolog jelent meg: mert ami ebben az értelemben természetes, az egyben racionális is, lévén hogy e szükségszerủ kapcsolatok pusztán a dolgok logikai kapcsolódási módját fejezik ki. Csakhogy az egyetemes determinizmusnak ez a fogalma viszonylag újabb keletű; még az antikvitás nagy gondolkodóinak sem sikerült teljes mértékben tudatára ébredniük. Az érdem a pozitív tudományoké; ezen a posztulátumon alapulnak, ezt bizonyították fejlődésük során. Amíg azonban ez az elv még nem volt meg, illetve nem szilárdult meg eléggé, addig a legcsodásabb eseményekben sem volt semmi olyasmi, ami ne lett volna teljes mértékben felfogható. Amíg nem tudták, hogy a dolgok rendjében van valami megingathatatlan és megváltoztathatatlan, amíg minden eseményben a dolgokhoz kapcsolódó akaratok művét látták, addig természetesnek találták, hogy ezek az akaratok vagy mások önkényesen megváltoztassák e rendet (Durkheim 2002: 38).

Hogy mennyire nem évült el Durkheim szemlélete, azt mi sem támasztja alá jobban, mint az, hogy mit gondol korunk egyik vezető ökológusa, Fikret Berkes a hagyományos ökológiai tudás (traditional ecological knowkedge, TEK) szerkezetéröl. Nézete szerint ez a tudás három részből áll. Egy áthagyományozott tudásból (knowledge), egy gyakorlatokból előálló tapasztalatból (practice) és egy hiedelemrendszerből (belief) (Berkes 2008: 7). Azt, hogy egyegy közösség hagyományos ökológiai ismereteiből mi számít tudásnak és mi számít minden igazolható alapot nélkülöző hiedelemnek, természetesen a nyugati ontológia és ismeretelmélet talaján álló ökológus dönti el. A nyugati tudományosság szempontjaival nem kompatibilis ökológiai ismereteket pedig ekképpen a kutató a vallási jelenségek közé sorolja (Berkes 2008: 11). Nemcsak a hagyományos ökológiai tudás iránt érdeklődő ökológusok, hanem az ökológiai és környezeti kérdésekkel foglalkozó antropológusok is hasonló módon közelítik meg, értelmezik és egyúttal osztályozzák a helyiek környezetszemléletét. A tudományos gondolkodás számára értelmezhetetlen helyi kategóriákat vallási jelenségként értelmezik. Ez egyaránt igaz az inkább deskriptív jellegü ökológiai antropológiai munkákra és a jelentősen preskriptívebb, aktívabb környezeti antropológiai írásokra (Sponsel 2017).

Ez a szemléletmód a hazai ökológiai kutatásokat is jelentős mértékben áthatotta, ahogy arról az Acta Ethnographica Hungarica 2017-es ökológiai antropológiai száma is tanúskodik. A tanulmánycsokor bevezető tanulmánya (Babai és Borsos 2017), valamint az azt követő írások egy olyan értelmezési keretet közvetítenek, miszerint a természettudományos alapokon álló ismeretek a valódi ökológiai tudás alapjai. Ezek szubsztrátumként minden etnoökológiai vizsgálódás kiindulópontjai - és ekképpen megváltoztathatatlanok a társadalomtudós kutatása által. Míg az ökológiai ismereteket lehet alkalmazni az emberi populációra (Borsos 2017: 55), addig a társadalmak elemzésére szolgáló fogalmi apparátus nem lesz releváns elemzési módszer a természettudományok számára. 
Rendkívül tanulságos Borsos Balázs 2005-ben megjelent kötete, amely máig az egyetlen elméleti igényü összefoglalása a nemzetközi ökológiai antropológiai irodalomnak (Borsos 2005). Az ökológiai antropológia irányzatainak és eredményeinek könyvbeli számbavételekor annak lehetünk tanúi, hogy az egyes kutatók és iskolák miképpen igyekeznek az ökológia normatív igényei szerint értelmezni, szelektálni az egyébként használói szempontjából egységes világszemléleteteket. Az iskolák közül utoljára a spirituális és szakrális ökológia irányzatát említi meg a szerző, vagyis egy olyan irányzatot, amely talán csak egy szempontból lép fel normatív igénnyel a hagyományos ökológiai tudással szemben, mégpedig azzal, hogy ugyan rendszerszerünek és relevánsnak tartja a TEK-ben csak hiedelemrendszerként értelmezett jelenségeket is, azonban azokat spirituálisnak, szakrálisnak minősíti (szemben a nem vallási jellegü ökológiai ismeretekkel). Vagyis ez az irányzat az érvényes ökológiai tudáson belül észleli a nyugati gondolkodás számára inkompatibilis elemeket - ugyanakkor ezen elképzeléseket egyértelműen a vallási jelenségek közé sorolva irracionálisnak, spirituálisnak minősíti (Borsos 2005: 81-84). Azonban a hagyományos ökológiai tudásnak ezen megközelítése is 15 évvel ezelött inkább megrökönyödést és elutasítást keltett akadémiai körökben. Joggal írja tehát a szerző, hogy:

Az antropológiai kutatásban tehát már teljes polgárjogot nyert az ökológia szakrális megközelítése, spiritualizálódása. A következő évek nagy kérdése, hogy vajon az etikus, mentalista környezetkép és az ehhez kapcsolódó erőforrás-menedzselés kialakul-e a természeti környezettel és annak felhasználásával foglalkozó modern tudományok között is. A jelen trendek ismeretében azonban valószínüleg még hosszú ideig várnunk kell arra, hogy a szakrális, spirituális etikus megközelítés a teljes modern tudományos életben megerősödjék - és aligha csupán a hagyományos akadémiai kutatás mellett kardoskodó biológiai ökológusok tiltakozása miatt (Borsos 2005: 84).

Röviden: az antropológiában jelenleg uralkodó ökológiai gondolkodás elfogadja azt a modernitásban megszilárdult szemléletet, amely az emberi kultúrát (és annak vizsgálatát) elválasztja a természeti jelenségek vizsgálatától. Míg a természettudományos módszereket és eredményeket problémamentesen, mintegy adottságként kezeli, addig a kulturális és társadalmi jelenségek között megkülönböztet racionális és irracionális (egyúttal vallásos, természetfeletti) elemeket, amelyeket az ökológiai antropológiai elemzésben külön, a természettudományos szemlélet által „igazolt” tudástól elválasztva kezel. Ez a szemlélet vezet ahhoz a Philippe Descola által kritizált nómenklatúrához, amely az elfogadott természettudományos diszciplínákhoz egy „etno-„, előtagot kapcsolva írja le etnobotanikaként, etnozoológiaként, etnofarmakológiaként vagy éppen etnopszichiátriaként egyes közösségek világképének egy szeletét (Descola 2013: 51). Valójában, hangzik egy további kritika, a TEK tudományos diskurzusokba való integrálásának igénye a metropol kutatói hozzáállás gondolata, és e törekvés egyik legfontosabb hozadéka az, hogy egyre növekvő mértékben koncentrálja a döntéshozók és tudósok kezében a környezetre vonatkozó tudást (Nadasdy 1999: 11-12).

A kérdés tehát az, hogy miképpen tud kitörni a saját maga emelte falak közül az antropológia és miképpen válhat az antropocénről szóló diskurzusok aktív és termékeny résztvevőjévé. Ahhoz, hogy erre a kérdésre választ lehessen adni, elöször is érdemes áttekinteni azt, hogy melyek az antropocén gondolatnak azon jegyei, amelyeket az antropológiai kutatás eddig mérlegre tett. 


\section{Kié az antropocén?}

Az antropocén nemcsak etimológiailag európai fogalom, hanem tartalmában és üzenetében is. Mert mi is az antropocén? A legáltalánosabb megfogalmazása szerint az a földtörténeti kor, amikor a Földön az emberi ágencia immár olyan befolyásossá (sőt dominánssá) válik, hogy már joggal tekinthető a globális geofizikai hatóerők egyikének (Purdy 2015: 3). Az emberi ágencia beemelése a természeti hatóerők közé egyúttal azt is jelenti, hogy a természet és az ember közötti különállás megszűnik. Ez a globális lépték adja egyrészt az antropocén erejét, kikerülhetetlenségét, ugyanakkor mutat rá annak hiányosságaira. Ugyanis a fogalom egy sereg heterogén jelenséget olvaszt egybe, amelyek elfedik, uniformizálják a sajátos, helyi folyamatokat (Arias-Maldonado 2015: 5-6; Biermann et al. 2015). Ami antropológiai szempontból különösen aggályos, az az, hogy a kulturális és ontológiai különbségeket is figyelmen kívül hagyja. Ez a földtörténeti korszak a földtudományokkal foglalkozó szakemberek szerint a 18. században kezdődött, a 20. században megerösödött, véget érni pedig vagy a távoli jövőben (Moore 2015: 515), vagy pedig az emberiség kihalásával fog (Danowski és Viveiros de Castro 2017: 5). Vagyis az antropocén az ember olyan (hasonlóan a tengerentúli gyarmatosítás kudarcos és morálisan elfogadhatatlan folyamatához) gyarmatosítási kísérlete, amelyben az alávetett oldalon a nem emberek közössége áll. Csak ebben az esetben a folyamatért nem egy-egy állam felelős, hanem maga az emberi nem. Ahogy az antropocén egyik teoretikusa fogalmaz:

Az antropocén fogalma azt a folyamatot írja le, amelyben az emberek egyre nagyobb mérték-
ben gyarmatosítják a természetet, nem tagadva ugyanakkor azt sem, hogy a gyarmatosítás kü-
lönböző módon zajlott és zajlik le különböző helyeken. Ugyanez vonatkozik az éghajlatválto-
zás globális hatásaira is - a jelenség ugyanaz, de a megnyilvánulásai eltérőek. Ugyanakkor az
antropocén gondolata azt sugallja, amint ezt a jelen könyv is hangsúlyozza, hogy az emberek és
a társadalmak természetéhez való viszonya folyamatosan homogenizálódik, és a helyi sajátossá-
gok relevanciája eltörpül a globális szocionaturális hibridizációs folyamat mellett. A különböző
társadalmak ugyan még mindig másképp gondolkodhatnak a természetről, de az, amit vele csi-
nálnak, meglehetősen egyöntetű (Arias-Maldonado 2015: 7).

Vagyis az antropocén felülír minden sajátos helyi szempontot, azt hangsúlyozva, hogy a folyamat a technológiai fejlődésnek és a globalizációnak köszönhetően a természet ember általi alávetésének egy általános és egyöntetű formája (Steffen et al. 2007). Ha elfogadnánk azt az álláspontot, amelyet az ökológiai antropológiai szakirodalom egy része is képvisel, akkor az antropológiai megismerés a nagy közös folyamat megértéséhez csupán annyiban járulhat hozzá, hogy esettanulmányokat hoz létre. Beszámolót adva arról, hogy egyes közösségek mennyit és milyen formában értenek meg az objektíven létező (vagyis a nyugati természettudományok által elfogadott) ökológiai folyamatokból, milyen sajátos (és egyúttal érdeklődésre számot tartó) gyakorlatokon keresztül tartanak kapcsolatot a környezetükkel, és milyen babonás nézeteket táplálnak. Mindez persze csak akkor igaz, ha az antropocént kizárólag a nyugati gondolkodás teremtette keretek között szemléljük.

Azonban egyre világosabb az, hogy az antropocén ennél jelentősebb kihívást jelent a társadalomtudományok, illetve azon belül az antropológia számára. Ahogy Amelia Moore, az 
antropocén antropológiájának egyik legbefolyásosabb kutatója fogalmaz, nemcsak a természet és társadalom kettősségét, hanem általában véve az antropológiai gondolkodás kereteit és fogalmi készletét kell átértékelnünk a beköszöntött új földtörténeti korban.

A globális környezeti változást megérteni kívánó fogalmak számos helyen hatással vannak gondolkodásunkra és cselekedeteinkre. Azt remélem, hogy az antropológia képes lesz teljes szélességében megragadni és életre kelteni azokat a lehetőségeket, amelyeket a planetáris gondolkodás által hozott új anthropos, bio- és geokozmológiák jelentenek. Új keretekre van tehát szükségünk, hogy lépést tarthassunk azokkal a hiteles érvekkel, amelyek egy újfajta kollektivitásról és a felelősségvállalásról szólnak (Moore 2015: 27).

Mindezek fényében jogos tehát a kérdés, hogy miképpen reflektáljon az antropológia az antropocén és egyúttal a globális ökológiai változások jelentette kihívásokra. Azon a megállapításon túl ugyanis, hogy az antropocén egy európai, intellektuális és elitista fogalom (Haraway 2016: 49), szükség van annak a megfogalmazására is, hogy miképpen néz ki az antropocén és a klímaváltozás nem európai, nem metropol perspektívából.

Nem nyújt ebből a szempontból kielégítő megoldást a poszthumanizmus gondolatának antropológiai befogadása sem. Ugyan egyre növekvő igény mutatkozik arra, hogy az emberközpontú antropológia mellett megjelenjen és teret nyerjen egy olyan poszthumán antropológia is (Raffles 2011; Tsing 2015), amelyben a világ telis-tele van áramló, emberek és nem emberek közt megoszló ágenciákkal; azonban - ahogy arra rámutatnak az arktikus térségben dolgozó kutatók - ennek a megközelítésnek is megvannak a maga buktatói, gyengeségei (DiNovelli-Lang 2013). Míg a természet és társadalom, az ember és nem ember között tételezett ellentét, illetve az ember központi szerepe e diskurzusokban rendre kritikai megvilágításba kerül, nehezen tudnak e munkák a nem európai ontológiákkal számot vetni. Ugyanis a poszthumanizmusnak e határok feloldására tett kísérleteiben óhatatlanul megjelenik egyfajta episztemológiai gyarmatosítás veszélye is, miszerint az egyes őshonos ontológiák kategóriarendszerét kisajátítva a kutató olyan poszthumán szimbiózisokat ír le vagy ír elö, amelyek az őshonos ontológiákkal immár nehezen összeegyeztethetők (DiNovelliLang 2013). Igaz, vannak kísérletek arra, hogy a poszthumán antropológiai munkák számot vessenek ezzel a csapdahelyzettel (Smart és Smart 2017), azonban megnyugtató módon nem sikerült megbirkózni a kérdéssel. Az antropológia egyik nagy esélye és feladata e diskurzus kiérlelésében, úgy vélem, a helyi példák és ontológiák felmutatása és minél radikálisabb képviselete.

A jelen tanulmány kereteit természetesen szétfeszítené az antropológiai leírások felvonultatása, így most megelégszem azzal, hogy a kortárs változásokat és egyúttal az ember és nem ember közötti viszonyokat egyetlen helyen, a szubarktikus Jakutiában röviden bemutassam. Jakutiában 2002 óta végzek terepmunkát, közel négy évet tartózkodtam a terepen, elsősorban Közép-Jakutia három falujában (Tandában, Küpben és Tyajában). A környezet és az ember, illetve a nem emberi entitások és emberek viszonyát már számos munkámban részletesen bemutattam az elmúlt években (Crate et al. 2017; Mészáros 2012a, 2012b, 2012c, 2013, 2016a, 2016b), így a jelen tanulmányban csak a legszükségesebb terepmunkaadatokra szorítkozom. 


\section{Az élő permafroszt táj}

Az északkelet-szibériai Jakutiát, ahol antropológiai terepmunkáimat 2002 óta végzem, az északi félgömb legszélsőségesebb éghajlati viszonyai jellemzik. A téli időszakban a hőmérséklet gyakran $-60 \mathrm{C}^{\circ}$ alá zuhan, nyáron pedig nem ritka a $+40 \mathrm{C}^{\circ}$-ot elérő hőség sem. A vegetációs időszak ennek megfelelően igen rövid. E rendkívül hideg éghajlatnak köszönhetően Jakutia talajának döntő többsége télen-nyáron fagyott, amelynek nyári időszakban csak a felső 1,5-2 méter vastagságú felszíne olvad fel. Ez a permafroszt talaj. Ilyen talajtípus az északi félgömbön Szibériában, Alaszkában és Kanada északi területein található, Jakutia talajának pedig lényegében az egésze örökké fagyott. A permafroszt nemcsak sajátos tájmorfológiát hoz létre, hanem egy rendkívül érzékeny és sérülékeny ökoszisztémát is, amelyhez a területre érkező szahák az elmúlt évszázadok során fokozatosan alkalmazkodtak (Takakura 2015; Crate et al. 2017). Ez a komplex adaptáció azonban nem kizárólag a gazdálkodás és a földhasználat leírásán keresztül érthető meg.

Számos antropológiai munka (elsősorban a poláris térségekben és Amazóniában) mutatott rá az elmúlt néhány évtizedben arra, hogy a tájat az azt használó közösségek érző, érzékelő közegként értelmezik (Crate 2006, 2012; Mészáros 2012a; Vitebsky-Alekseyev 2015; Prokopeva 2015; Takakura 2015). Igaz ez a jakutiai szahákra is. Vagyis a helyiek nemcsak materiális tulajdonságokkal övezik fel a réteket és a tavakat, hanem élettel, lélekkel is. Ennek megfelelően a tájak érzékenyen reagálnak, sőt válaszolnak akkor, amikor az emberekkel kapcsolatba lépnek (Tabyrynova 2010). Az élő tájak a helyiek számára sajátos személyiségvonásokkal is rendelkeznek, amelyeket a velük intenzív kapcsolatban álló vadászok, halászok vagy lovászok kiismertek. Vagyis egy helyi szaha jó eséllyel tudja, hogy miképpen kell és érdemes viselkedni egy-egy közeli réttel vagy tóval, ahogy azt is ismeri, hogy hogyan lehet kommunikálni velük. Nem meglepő tehát, hogy az élő tavakat rendszerint nagymamának (ebe) nevezik a szahák.

A rétek és a mezők nem véletlenül foglalnak el központi szerepet a szahák világában. Az örökké fagyott, permafroszt talajon kialakult hidrokarsztos süllyedékek és az azokban létrejövő rétek és tavak tették ugyanis lehetővé a szahák számára azt, hogy ebben a szubarktikus térségben is megőrizzék nagyállattartó életmódjukat (Bychkova-Jordan és Jordan-Bychkov 2001; Mészáros 2012a) - ezért e tájak szerepe felbecsülhetetlen a számukra. Az Aldan és a Léna folyók könyökében (Közép-Jakutiában) ezek a termokarsztos mélyedések az eltérő becslések szerint a teljes felszín 17-30 százalékára terjednek ki (Katamura et al. 2006; Telbisz és Nagy 2008). Az egyes mélyedések mérete igen változó. Esetenként 500 négyzetkilométernél is nagyobbak, amelyeken ma már sok kis település, akár kisebb városok is elhelyezkedhetnek, máskor azonban csak alig 100 méter sugarú, név nélküli erdei tisztások. Szaha nyelven ezeket a süllyedéseket alaasnak nevezik. Az alaas olyan füves pusztai vegetációval rendelkező rét a vörösfenyők uralta tajgában, amelynek közepén egy tó, vagy pedig egy tó kiszáradt, mocsaras, süppedékes medre található (Crate 2006: 3); egyben olyan sajátos szaha táj is, amely részben antropogén eredetü. Az alaasok kialakulása ugyanis egy komplex folyamat. A talaj felolvadásakor először erdei mocsarak (düöde) jöttek létre, melyeknek vízzel borított felülete egyre nőtt. Ezek a tavak azután később maguktól kiszáradtak vagy az ott élő szaha közösségek csapolták le őket (Bosikov 1991: 112). Az alaasok ma a jakutiai szénagazdálkodás és legeltetés legfontosabb színterei. 
Az alaas tehát egy olyan entitás, amely ember nélkül nem képzelhető el, így a klímaváltozás okozta ökológiai változások nem csupán egy tájra, és azon keresztül közvetve az emberi közösségre hatnak, hanem egy olyan sürün szőtt kapcsolathálót alakítanak át, amelynek az élő, érző tájak és az emberek egyaránt részei. Amikor tehát a globális klímaváltozás jelenségei felerősödnek az arktikus térségekben, egy olyan sérülékeny világ kerül nyomás alá, amely ugyan tekinthetö ökoszisztémának vagy ökotopok halmazának is, de a helyiek nem így tekintenek rá.

Különösen azért jelent nagy kihívást Jakutiában a klímaváltozásra adott válasz kidolgozása, mert az arktikus térségekben a globális éghajlati és környezeti anomáliák fokozott mértékben jelentkeznek (Goldstein 2009: 41-43). Az egyik érzékelhető hatása a felmelegedésnek éppen a permafroszt talaj fokozott eróziója és elvizesedése (Fedorov és Konstantinov 2009). Ez egyaránt vonatkozik a lágy szárú vegetációval borított termokarsztos mélyedésekre, valamint az erdőkre. Amikor tehát elmocsarasodik egy tó partja vagy éppen zsombékos lesz egy rét, az a szahák számára nem csupán (vagy nem elsősorban) egy ökológiai folyamat, hanem a közösség egy tagjának betegsége. Hasonlóképpen az új állatfajok megjelenése, a tó vizének és halfaunájának változása, a zsákmányállatok eltünése és a halfogás csökkenése mindenekelőtt a közösség egy tagjának megváltozott viselkedésére utal. Vagyis a helyiek számára elsősorban az élő, érző tájak sajátos közegében értelmezhető és értelmeződik a globális klímaváltozás. Másképpen fogalmazva: nem éghajlati anomáliáktól és megváltozott ökológiai viszonyoktól övezve, hanem beteg és holt tavak, bosszúálló és megalázott rétek közegében lépnek be a szahák az antropocén világába.

\section{Élők és holtak, élők és élettelenek}

Amikor a magyar olvasó számára úgy érvelek, hogy a rétek és a tavak egy része élő, személyiséggel rendelkező entitás, és a permafroszt táj degradációja, elvizesedése a nyugati tudományos gondolkodás számára irracionális - és egyúttal vallásinak tekintett - perspektívából is megérthető, akkor szükségesnek tűnik az, hogy Jakutia jelen ökológiai kihívásait ebből a szemszögből is érzékeltessem. Mielőtt azonban hozzáfognék, érdemes egy-két magyarázó megjegyzést füzni ahhoz, mit is jelent a szahák számára az, hogy egy tó, egy rét vagy bármilyen más entitás él, vagyis „élőlény”.

A szahák elképzelései szerint minden földi élőlénynek, így a tavaknak és réteknek is egyaránt rendelkezniük kell testtel és lélekkel. E kettősség azonban nem jelenti azt, hogy a lélek és a test (vagyis a fizikai megjelenés és a spirituális tartalom) egymástól elválasztható, egymástól függetlenül értelmezhető jelenség lenne (Viveiros de Castro 1998; Bird-David 1999; Descola 2013). Másképpen fogalmazva, a szahák szerint sem test nélküli, sem lélek nélküli létezők nem sorolhatók az emberekkel azonos kategóriába eső, élő entitások közé. Emiatt nemcsak azért tekinthető élőnek egy tó vagy egy rét, mert lelke, hanem azért is, mert érzékelhetö teste is van. A termokarsztos mélyedésekben létrejött tavak és a rétek a velük kapcsolatba kerülő ember számára végesek, határral rendelkeznek, így észlelhető testük is van. Az erdőt például azért nem tekintik élőnek a szahák és ruházzák fel sajátos személyiségje-

gyekkel, mert annak nincs körülhatárolható, érzékelhető teste. Továbbá a szahák számára az erdőnek nincsenek (test)részei sem. A tavak esetében ezzel szemben meghatározható, hogy 
hol van a fejük és a lábuk, ahogy az is, hogy merre néznek (Mészáros 2016a). Ez a tájolás nemcsak elméleti jellegü elképzelés, hanem szorosan összefügg a gyakorlatokkal is. Meghatározza például, hogy melyik irányból illendő egy alaasra lépni, hol alkalmas felállítani a lebegőhálót és mely helyeken érdemes felépíteni az istállót, színt vagy felverni a sátrat. $\mathrm{Az}$ alaasoknak, réteknek emiatt van saját nevük - az erdőknek, erdőrészeknek pedig rendszerint nincsen (Mészáros 2013).

A tavak testét a medervonal határolja le, a réteket az azokat körülvevő erdő. A tavak és a rétek lelkét (a maga testiségében) pedig, hasonlóan az emberi lélekhez, csak akkor lehet meglátni, ha az elhagyja a testét - elsősorban az álomlátás, illetve révülés során. Azonban spirituálisan akkor is lehet érzékelni a tavat, ha egy szaha a tó közelébe ér (Yamada 2006). Egyik jakutiai beszélgetőtársam, aki pézsmapocokvadászként és halászbrigád-vezetőként az 1970-es évektől kezdve igen szoros kapcsolatban állt a környékbeli tavakkal, elmondta, hogy ő már találkozott a N’id’ili-tó lelkével, amelyet egy hínárhajfonatú idős asszonyként írt le az interjú során. Vagyis a tavak teste sem törvényszerüen tartalmazza a tavak lelkét, hanem azok szabadon, a maguk testiségében érintkezhetnek az emberekkel.

Ez nem is meglepő, hiszen a szahák a test és a lélek közötti viszonyt dinamikusan képzelik el. Az emberi test nem minden esetben tartalmazza az emberi lelke(ke)t. A legáltalánosabb feltevés szerint egy ember lelke négy részből áll. Az egyik szaha nyelven a sür, amelyet leginkább a test életerejének lehet tekinteni. Emellett az embernek van három lelke ( $k u t)$. Az egyik az ije kut (vagyis az anyalélek), a másik a buor kut (földlélek), a harmadik pedig a szellőlélek (salgyn kut). Míg az előbbi kettő szigorúan a testbe zárva él, a harmadik álomlátáskor elhagyhatja a testet. Ilyenkor kis emberke vagy valamilyen rovar (elsősorban légy és pók) formájában láthatóvá válik (Kolodesnikov 2000; Alekseev et al. 2012: 333-334). Vagyis az a különös helyzet fordul elő, hogy a testnek is van immateriális jellegű alkotója, a sür, és a léleknek is van testi megjelenése (kis ember, rovar). Vagyis a test és a lélek egymással nem szembeállitható fogalmak, hanem mindegyik tartalmaz egy-egy részt a másikból.

Mintmindenélőorganizmus, a tájakakármegishalhatnak. Egyikterepmunkahelyszínemen egy Badarannaakh nevü mező és tavacska alatt 1978-ban kísérleti atomrobbantást hajtott végre a szovjet állam (Takada et al. 1999). A helyiek a területet és a mellette lévő Nychalaakh és D’ukojan tavakat azóta halottnak (ölbüt) tekintik. Ez természetesen nem jelenti azt, hogy e tavak kiszáradtak volna, vagy hogy ne élnének ott halak, ne pihennének meg ott vízimadarak - egyszerüen a helyiek szemében már nem élők ezek a tájak, így nem is állnak vele sem gazdasági, sem spirituális kapcsolatban. Emellett, ahogy más élőlények, egy tó vagy egy rét lehet beteg vagy sérült is. Éppen ezért meg is lehet gyógyítani őket.

Azonban nem minden rét vagy tó élő. Ahogy az ojibwák esetében Alfred Hallowell rávilágított, csak a mi szemszögünkből tekinthető egységesen minden kő kőnek. Az ojibwák meglepő határozottsággal különbséget tudnak tenni az élő és az élettelen kövek között (Hallowell 1960). Igaz ez a szaháknál is. A területet nem ismerők (olykor még a szahák esetében is) számára egységesen tavaknak tünnek azok az élővizek, amelyekre a helyiek hol küöl-ként (tó), hol ebe-ként (nagyanya) hivatkoznak. Rendszerint a helyiek, és azok közül is elsősorban azok, akik szoros kapcsolatban állnak egy-egy területtel, tudnak nyilatkozni arról, hogy egy ott elterülő tó vagy egy rét a létezők mely osztályába sorolható. E kategóriarendszer (másképpen nevezve ontológiai rendszer) minél alaposabb megértése nemcsak abban segít, hogy a korábban egyöntetűen vallási, sámánisztikus jelenségnek minősített eljárásokat és szemlé- 
letmódokat mélyebben és pontosabban értelmezhessük, hanem abban is, hogy a tájhasználathoz köthető egyes tevékenységek (halászat, csapdázás, kaszálás, sőt újabban a természetvédelmi szolgálatok munkájában való segítségnyújtás) morális hátterét megérthessük.

A tavak/rétek osztályozásának, illetve a klímaváltozás okozta adaptáció pontosabb megértésnek érdekében 2009 óta vizsgálom immár fókuszáltan azokat a gyakorlatokat, amelyek a leghosszabb távú tartózkodást igénylik a tavaknál. E három tevékenység, vagyis a jég alatti húzóhálós halászat, a pézsmapocok-csapdázás, illetve a jég alatti lebegőhálós halászat gyakorlatai eltérő képet adnak arról, hogy mit is jelent a helyi ontológia, mik is a tavak, és mik az ebben a viszonyban megszerzett zsákmányok. E tevékenységek belső logikájáról már írtam (Mészáros 2019), ezért e helyen csak két megvilágító erejű terepmunkaélményemet osztanám meg röviden.

Az egyik egy 2013-as húzóhálós halászathoz kötődik, amelyet egy Luku nevü tavon folytattunk. A húzóhálós halászat minden esetben közösségi tevékenység, nem is lehet 10-12 embernél kevesebb résztvevővel kivitelezni. A halászatot egy brigediir-nek nevezett vezető irányítja, akinek az első feladata a megfelelö nagymama kiválasztása, ahová a húzóhálót bevetik. A halászat előtti megbeszélés során az egyik fó érv a Luku kiválasztása mellett az volt, hogy az utóbbi időben nem nagyon látogatták meg, és nem adtak neki ajándékot, úgyhogy ideje lenne megetetni. Az elhanyagolt, nem látogatott és ajándékokkal nem illetett barátok ugyanis könnyen megharagudhatnak. A kérdésre, hogy a sokáig nem látogatott nagymama ad-e több halat, a válasz csak nevetés volt: „Tudod, olyanok ezek, mint mi. Valaki azt szereti, ha sokszor látogatják meg, van, akik pedig nem lát minket szívesen!”

Egy másik alkalommal 2013 őszén pézsmapocok-csapdázásra indultunk a Bere-tóhoz. A Bere, hasonlóan a nagy tavakhoz, nagymamaként volt számon tartva a helyi vadászok és halászok között. Azonban megdöbbenésemre, ellentétben a húzóhálós halászatokkal, a munka kezdetén társam nem adott ajándékot, nem adott eleséget a tónak - ahogy az egyébként a nagymamákkal való fizikai kapcsolat esetén általános. A kérdésemre, hogy akkor miképpen fogadhatja el a viszontajándékot a Berétől, Afanasij azt felelte: „Ez most nem igazi vadászat. A pézsmapocok nem a Bere-tóé, olyan az inkább, mint a betegsége. Nézzed meg a partot, hogy feltúrja. Minden mocsaras lesz ott, ahol él." Amikor pedig elmagyarázta, hogy egy sikeres csapdaállításnál (amelybe ez esetben 11 pézsmapocok fulladt bele) a legjobb az, ha a csapdázó egyetlenegy élő pézsmapockot sem hagy meg, egyértelművé vált, hogy az élő tó, a pézsmapocok és az ember között másfajta kapcsolat van, mint a jég alatti húzóhálós halászat esetében a kárász, a tó és a halász között. Míg az első esetben egy baráti csereviszony áll fenn a halász és a tó között, a második esetben az ember mintha a nagymamának a gyógyítója lenne, aki eltávolítja betegségének okozóját. Azonban mindkét esetben a vadászati, halászati gyakorlat az tó emberszerüségével állt összhangban.

Mindezek ellenére hiba lenne valamiféle egységes és minden helyi számára egyértelmű kategóriarendszerként értelmezni az eddigiek során felvázolt ontológiát, amelyben egyes tájak egy része az emberrel azonos státuszt foglal el a helyi közösségben. Nemcsak a szovjet és az azt követő föderatív időszak oktatási rendszere és tömegkommunikációs eszközei hatottak a helyiek tájról alkotott elképzeléseire, hanem az elmúlt két évtizedben az arktikus térségben fokozottan érezhető globális klímaváltozás is. És ezek a változások igen sokfélék. Ưj, korábban ismeretlen fajok jelentek meg (Ksenofontov et al. 2019), a tavak külalakja megváltozott, a rétekből tavak lettek (Crate 2012), a halászat és vadászat korábban sikeres 
módszerei csődöt mondtak (Ksenofontov et al. 2017). Vagyis az éghajlati anomáliák kérdésessé tették a korábban müködőképes (vagyis az adott ökotophoz megfelelő mértékben adaptálódott) világkép és kategóriarendszer érvényességét (Crate 2008).

Úgy is lehet tehát fogalmazni, hogy a szahák fordított utat járnak a globális éghajlati változások megélése során, mint ahogy azt a nyugati gondolkodás feltételezi. A szahák ugyanis az elmúlt évtizedig folyamatosan az antropocénben éltek. Számukra nem volt kétséges az, hogy az ember és környezete egymástól kategoriálisan nem az emberi faj és egyéb entitások nyugati különbségtételével választható el, mivel az ő világukban a kategoriális határ az élőlények (és ekképpen a helyi közösség tagjai), illetve az élettelen (a helyi közösségen kívül álló) entitások között mutatkozik meg. A közösség tagjai pedig lehetnek emberek, tavak, medvék, lovak vagy akár egyes fák is. Másképpen fogalmazva, a társadalmi ágencia a szahák számára nem volt elválasztható a természeti hatóerőktől. Ök eddig is azt gondolták, amit ma az antropocén képviselői: vagyis azt, hogy az emberi ágencia (vagyis a szahák cselekedetei) szerves részei a helyben megfigyelhető természeti hatóerőknek. Egy közülük. És fordítva: a természeti hatóerők valójában társadalmi ágenciák is, és mint ilyenek, a közösségbeli viselkedésbe illeszkednek bele.

Ezért is hagyják el fokozatosan a maguk antropocénjét a szahák. A közösség nem emberi tagjai ugyanis, ahogy azt a helyiek értelmezik, elfordultak tőlük és nem hajlandók többé kommunikálni, szóba állni velük. Sőt esetenként - köszönhetően azoknak az emberi tevékenységeknek, amelyek nem fejeztek ki irántuk tiszteletet - ellenségessé, bosszúállóvá is váltak (Slepcov-Sylyk 2013). Másképpen fogalmazva, az emberek a közösségen belüli viselkedési normákat megsértették, így a nem emberek (legalábbis részlegesen) kiléptek a közösségből. Ezzel a korábban egységes közösség egyre inkább a szétválás jegyeit mutatta -az emberi közösség a tavakban, rétekben és állatokban egyre inkább kiismerhetetlen, vad természeti jelenségeket ismert fel (Mészáros 2012b). Vagyis a szahák egyre inkább kilépnek az antropocénből, megérkezve egy új, korábban ismeretlen világba.

Az előző oldalakon röviden ismertetett szaha példa, úgy vélem, elég határozottan rávilágított arra, hogy a kortárs éghajlati anomáliák értelmezése, érzékelése nem csupán a nyugati tudományosság nyújtotta keretek és kategóriák között lehetséges. Ez természetesen arra is rámutat, hogy az ökológiai változásokhoz való közösségi alkalmazkodás kimunkálása során a helyi közösségek olyan, az európai világlátással összeegyeztethetetlen elképzeléseket és eljárásokat mozgósítanak, amelyeket az adott közösségből kilépve akár érvénytelennek is tekinthetünk. A kérdés tehát az, hogy ezen „egzotikus” példák, kategóriarendszerek és adaptációs technikák megismerése, leírása és közvetítése miként járulhat hozzá a jelen ökológiai kihívásainak megoldásához. Vagyis, hogyan tud az antropológia az antropocénről szóló eszmecserékhez hatékonyan hozzájárulni?

\section{Az ontológiai antropológia kínálta megoldás}

Bronislaw Malinowski állomásozó terepmunkája óta az antropológia egyik leghatározottabban megfogalmazott feladata és egyúttal módszere, hogy minél hitelesebben és pontosabban adja vissza a bennszülöttek perspektíváját. A kérdés az, hogy meddig mehet el ebben a törekvésében az antropológia. Vajon hová vezet az az eljárás, amikor az antropológiai vizsgálat során a kutató már nem a saját tudományos kategóriarendszeréből kiindulva (pl. rokonság, 
folklór, gazdálkodás, ökológia stb.) kérdez rá egyes közösségek sajátos eljárásaira, világképére, hanem fordítva - az egyes bennszülött ismeretelméleti és ontológiai rendszerekből kérdez vissza a saját (nyugati vagy tudományos) kategóriáinak érvényességére? Az ontológiai antropológia legjelentősebb kihívása éppen ennek a kérdésnek a megválaszolása (Holbraad és Pedersen 2017: 13-15).

A válaszadás egyik kézenfekvő területe az ontológiai antropológia kibontakozásának kezdeteitől az ökológiai és környezeti antropológia kérdései voltak. Ez nem is meglepő, hiszen a vadászó-gyüjtögető közösségek vizsgálatának kezdeteitől kérdéses volt, hogy hol húzódik pontosan a kultúra és a természet közötti határ a természeti népek (Naturvölker) esetében. Leghatározottabban a szibériai rénszarvastartó és nagyjószágtartó közösségek (Broz 2007; Willerslev et al. 2015), valamint az amazóniai kertművelő és egyben vadászó-gyüjtögető közösségek leírása során fogalmazódott meg az, hogy sokszor elmosódott a határ a természetes vegetáció és a kert vagy a mező és a legelő között (Descola és Pálsson 1996: 10; Descola 2013: 28).

A társadalom és a természet kategóriái bennszülött kategóriákkal való szembesítésének egyik radikális eredménye az Eduardo Viveiros de Castro által javasolt „multinaturalizmus” fogalma (Viveiros de Castro 2004). A szerző alapvető különbséget lát a nyugati ontológia és az amazóniai között. Míg a nyugati ontológia a természetet állandó, minden közösség számára egyaránt adott háttérként, közegként értelmezi, amelyre az egyes közösségek más kulturális eszköztárral/jelrendszerrel látnak rá, addig az amerikai indián ontológiák univerzális adottságnak azt a társadalmi kapcsolatot tekintik, amely az egyes entitásokat (embereket, növényeket, állatokat stb.) egy nagy közösségbe köti össze. A természet e nézet szerint egy változó jelenség, amely a nagy közös társadalomban elfoglalt helyzete szerint eltérőképpen áll az egyes létezők (tapírok, sámánok és halak) rendelkezésére. Vagyis nem a társadalom, hanem a természet sokféle. Ennek következtében nem az az érvényes antropológiai kérdés, hogy miképp is látják a környezetüket egyes közösségek, hanem az, hogy mi is, mikből, kikből áll ez a környezet.

Ez a radikálisnak tűnő álláspont lehetővé teszi azt, hogy a természet és a társadalom viszonyát mérlegre tevő ontológiai antropológiai diskurzusok olyan kérdéseket érintsenek, amelyeket az ökológiai problémákat vizsgáló természettudományos érdeklődés releváns módon nem vethet fel. Ugyanis egy klimatológus sosem teheti fel azt a kérdést, hogy egy hegy vagy a déli szél élőlény-e, és ha igen, akkor mit érez, ahogy azzal sem foglalkozhat egy hidrológus, hogy a falutól délre elterülő tó ember-e, és emberként milyen személyiségvonásokkal rendelkezik. Folytatva ezt a gondolatmenetet, azzal sem vethet számot egy ökológus, hogy az így előálló összetett kapcsolatrendszerben milyen felelősség hárul az „emberekre”. Antropológusként azonban minderre nemcsak lehetőségünk van, de szinte kötelességünk is számot vetnünk az eltérő ontológiák következményeivel. A feladat tehát adott: kölcsönös viszonyba kell hozni az eltérő ontológiákat (vagyis a bennszülöttek perspektíváit) a tudományos diskurzusokkal (Viveiros de Castro 2013: 475).

Az, hogy mindez lehetséges, ma már egyre egyértelműbb tudományágunkban (Jupiter 2017), ahogy az is egyre nyilvánvalóbb, hogy a szabályozási kérdésekben is érdemes érvényre juttatni a bennszülött környezetérzékelést és ontológiákat (Stering et al. 2017). Ugyanis nem mindegy, hogy milyen kategóriák segítségével gondolkodunk az antropocénről, mivel úgy tűnik, hogy nem visz messzire az az eljárás, amelynek keretében igyekszünk megszelídíteni, redukálni a bennszülött világokat és fogalmakat valami olyanra, ismerősre, amivel azonosulni tudunk (Spyer 2011: 62). 
Számot vetve az ontológiai antropológia kínálta megújulás lehetőségeivel, ma már egy sereg olyan törekvés ismeretes, amely a kölcsönösség szempontjait érvényre kívánja juttatni az antropocén ökológiai kihívásaira adott válasz megfogalmazása során. E válaszok némelyike akár ellent is mondhat a tudományos kategóriáknak akkor, amikor számba veszi a fenntarthatóság helyi lehetőségeit (West 2005). Ennek megfelelően ismeretesek olyan konkrét programok is, amelyek például a vadászat kapcsán igyekeznek az eltérő moralitásokat és ontológiákat egymással összhangba hozni (Blaser 2009). Ez a fajta antropológiai gondolkodás nemcsak a környezet jobb megértésében kap egyre jelentősebb szerepet, hanem szóhoz jut akkor is, amikor egyes államok saját természetvédelmi feladataikat hatékonyan kívánják ellátni (Heckenberg et al. 2017). Ma már egyre több példa támasztja azt alá, hogy a bennszülött ontológiák nemcsak alkalmasak arra, hogy kölcsönös viszonyba kerüljenek a tudományos gondolkodással, hanem sikeresnek bizonyulnak alkalmazásuk során is - például akkor, amikor egy-egy terület biodiverzitásának megőrzése a cél (Ruru et al. 2017). Sajnos, mindezekre éppen Oroszország és Jakutia esetében egyelőre kevés esély mutatkozik.

Röviden, az elmélyült, saját kategóriáit felfüggeszteni képes antropológiának, úgy tűnik, egyre jelentősebb szerepe lesz abban, hogy morálisan elfogadható válaszokat fogalmazzunk meg az antropocénben a környezetünkkel, a fenntarthatósággal és a széles értelemben vett földi közösséggel kapcsolatban. Ennek fontos eszköze az antropológia egyik alapkategóriájának szükségszerü megkérdőjelezése lehet. Ez a kategória pedig a másság.

\section{Más-ság és „mi-ség”}

Az antropológia és a néprajztudomány már elnevezésében is azt sugallja, hogy az embert, az emberek csoportjait kutatja. Mindazt tehát, ami kulturális/társadalmi jelenség, a természet pedig e nézet szerint mindaz, ami nem kulturálisan, társadalmilag megteremtett, hanem már korábban, attól függetlenül is létező. A környezetébe helyezett ember vizsgálata ennek megfelelően arról szól, hogy milyen kapcsolatban áll a kutatói figyelem fókuszában álló ember az őt körülvevő különnemű, más entitásokkal.

Nurit Bir-David a dél-indiai erdei vadászó-gyüjtögető najakák között végzett terepmunkája során kiérlelt egyik antropológiai következtetése az, hogy a másság, a másikra való összpontosítás olyan, a modernitásban gyökerező ismeretelméleti eljárása az antropológiának, amely konfliktusban áll egyéb, a fajok és létezők között közvetíteni kívánó episztemológiákkal. Azt a módot, ahogy a najakák saját környezetüket érzékelik, és ahogy a benne élö egyéb entitásokkal érintkeznek, Bird David relációs episztemológiának nevezi. Ezen ismeretelmélet szerint nem az a fontos, hogy elkülöníthetö és jól meghatározható lényegi tulajdonságait észleljük valami más entitásnak a saját jól meghatározható szemszögünkből, hanem az, hogy az egymással kapcsolatban álló entitások az egymással való kapcsolatukban éljék meg azt a közös észlelési horizontot, amelyben cselekedeteik értelmet nyernek (Bird-David 1999: 77). Másképpen fogalmazva, akkor tudja meg egy ember, hogy miféle entitással áll szemben, amikor azzal kapcsolatba lép. Hogy egy elefánt esetleg egy szellem (devaru), vagy valóban egy elefánt, az csak az emberrel fenntartott kapcsolatából válik egyértelművé. A két ismeretelméleti rendszer közötti különbség egyúttal azt is eredményezi, hogy mást jelent tudni az egyik, illetve a másik rendszerben: 
A tudás az első esetben azt jelenti, hogy az egyén reprezentációkat hoz létre a világban lévő egyéb létezőkről, amelyeket aztán pontosít és alkalmaz. Míg a második esetben a világban létezés készségét fejleszti ki az egyén, fokozatosan finomítva, gazdagítva azt a tudatosságot, ahogy a környezetében létezik. A tudás a második esetben az egyént körülvevő létezőkkel való kapcsolatból sarjad és a kapcsolat által létezik. Ez a tudás a környezet megosztottságán (dividuating), mintsem kettősségén (dichtomizing) alapul, és ekképpen a különbségeket elnyelő „mi-ség”re összpontosít, mintsem a különbségeket felnagyító és a közös jegyeket elfedő „más-ság”ra. A „gondolkodok tehát vagyok” elvével szemben itt a „viszonyulok, tehát vagyok”, illetve „akként tudok, ahogy viszonyulok" elve áll (Bird-David 1999: 77-78).

Ahogy egyre nagyobb szükség mutatkozik arra, hogy más fajokkal való rokonságunkat felismerjük (Haraway 2016), és arra, hogy a fajok közötti pidzsin nyelvet megértsük (Kohn 2013: 131-133), úgy az antropológiának is egyre komolyabb szerepet kell vállalnia a megindult párbeszédben. Közvetítve világképek, világok és moralitások között.

\section{Hivatkozott irodalom}

Alekseev, A. N., Romanova, E. N. és Sokolova, Z. P. (2012): Jakuty, Saha. Moszkva: Nauka.

Arias-Maldonado, Manuel (2015): Environment and Society: Socionatural Relations in the Anthropocene. London: Springer. DOI: https://doi.org/10.1007/978-3-319-15952-2

Babai, Dániel és Borsos Balázs (2017): Ecological Anthropological Research in Hungary. Acta Ethnographica Hungarica 62(1): 7-30. DOI: https://doi.org/10.1556/022.2017.62.1.1

Berkes, Fikret (2008): Sacred Ecology. London - New York: Routledge.

Biermann, Frank, Xuemei Bai, Ninad Bondre, Wendy Broadgate, Chen-Tung Arthur Chen, Pauline Dube, Jan Willem Erisman, Marion Glaser, Sandra van der Hel, Maria Carmen Lemos, Sybil Seitzinger és Karen C. Seto (2016): Down to Earth: Contextualizing the Anthropocene. Global Environmental Change (39): 341-350. DOI: https://doi.org/10.1016/j.gloenvcha.2015.11.004

Bird-David, Nurit (1999): „Animism” Revisited: Personhood, Environment, and Relational Epistemology. Current Anthropology (40): 67-91. DOI: https://doi.org/10.1086/200061

Blaser, Mario (2009): The Threat of the Yrmo: the Political Ontology of a Sustainable Hunting Program. American Anthropologist 111(1): 10-20. DOI: https://doi.org/10.1111/j.1548-1433.2009.01073.x

Blaser, Mario (2013): Ontological Conflicts and the Stories of Peoples in Spite of Europe: Toward a Conversation on Political Ontology. Current Anthropology 54(5): 547-568. DOI: https://doi.org/10.1086/672270

Boas, Franz (1936): History and Science in Anthropology: A Reply. American Anthropologist, New Series 38(1): 137-141.

Borsos Balázs (2005): Elefánt a hídon - Gondolatok az ökológiai antropológiáról. Budapest: L’Harmattan.

Borsos, Balázs (2017): Ecology + Anthropology = Ecological Anthropology? Acta Ethnographica Hungarica 62(1): 31-52. DOI: https://doi.org/10.1556/022.2017.62.1.2

Bosikov, N. P. (1991): Evoluciia alasov central'noj Iakutii. Jakutszk: Institut Merzlotovedenii.

Broz, Ludek (2007): Pastoral Perspectivism: A View from Altai. Inner Asia 9(2): 291-310. Interneten: https://www. jstor.org/stable/23614996 (letöltve: 2019. január 26.).

Bychkova-Jordan, Bella és Terry Jordan-Bychkov (2001): Siberian Village, Land and Life in the Sakha Republic. Minneapolis: University of Minnesota Press.

Candea, Matei (2011): Endo/Exo. Common Knowledge 17(1): 146-150. DOI: https://doi.org/10.1215/0961754X -2010-046

Caney, Simon és Derek Bell (2011): Morality and Climate Change. The Monist 94(3): 305-309. DOI: https://doi. org/10.5840/monist201194315

Chandler, David és Julian Reid (2018): 'Being in Being': Contesting the Ontopolitics of Indigeneity. The European Legacy 23(3): 251-268. DOI: https://doi.org/10.1080/10848770.2017.1420284

Crate, Susan A. (2006): Cows, Kin and Globalization. An Ethnography of Sustainability. Lanham: Altamira Press.

Crate, Susan A. (2008): Gone the Bull of Winter? Grappling with the Cultural Implications of and Anthropology's Role(s) in Global Climate Change. Current Anthropology 49(4): 569-595. PMID: 19230265. 
Crate, Susan A. (2011): „We are going Underwater.” Natural History 119(5): 20-29.

Crate, Susan A. (2012): Climate and Cosmology: Exploring Sakha Belief and the Local Effects of Unprecedented Religion in North-Eastern Siberia, Russia. In Environmental and Climate Change: Suffering, Values, Lifestyles. Dieter Gerten és Sigurd Bergmann (szerk.). London - New York: Continuum, 175-199.

Crate, Susan A., Mathias Ulrich, Otto J. Habeck, Roman Desyatkin, Aleksander Fedorov, Tetsuya Hiyama, Yoshihiro Ijima, Stanislav Ksenofontov, Mészáros Csaba és Hiroki Takakura (2017): Permafrost Livelihoods: A Transdisciplinary Review and Analysis of Thermokarst-based Systems of Indigenous Land Use. Anthropocene (18): 89-104.

Crutzen, Paul J. és Eugene Stoermer (2000): The „Anthropocene”. IGBP Newsletter (41): 17-18.

Danowski, Deborah és Eduardo Viveiros de Castro (2017): The Ends of the World. Cambridge: Polity Press.

Degler, Carl N. (1989): Culture versus Biology in the Thought of Franz Boas and Alfred L. Kroeber. New York - Oxford - Munich: Berg. (German Historical Institute, Annual Lecture Series No. 2.)

Descola, Philippe (2013): Beyond Nature and Culture. Chicago: Chicago University Press.

Dijksterhuis, Fokko Jan (2012): The Mutual Making of Sciences and Humanities: Willebrord Snellius, Jacob Golius and the Early Modern Entanglement of Mathematics and Philology. In The Making of the Humanities: Volume II: From Early Modern to Modern Disciplines. Rens Bod, Jaap Maat és Thijs Weststeijn (szerk.). Amsterdam: Amsterdam University Press, 73-92.

DiNovelli-Lang, Danielle (2013): The Return of the Animal: Posthumanism, Indigeneity, and Anthropology. Environment and Society: Advances in Research (4): 137-156. DOI: https://doi.org/10.3167/ares.2013.040109

Durkheim, Émile (2002): A vallási élet elemi formái. A totemisztikus rendszer Ausztráliában. Budapest: L’Harmattan.

Fabian, Johannes (2002): Time and the Other. How Anthropology Makes its Object. New York: Columbia University Press.

Fedorov, Aleksander N. és Petr Ya Konstantinov (2009): Response of Permafrost Landscapes of Central Yakutia to Current Changes of Climate, and Anthropogenic Impacts. Geography and Natural Resources 30(2): 146-150. DOI: https://doi.org/10.1016/j.gnr.2009.06.010

Hallowell, Alfred Irving (1960): Ojibwa Ontology, Behavior, and World View. In Culture in History. Essays in Honor of Paul Radin. Stanley Diamond (szerk.). New York: Octagon Books, 19-51.

Haraway, Donna (2015): Anthropocene, Capitalocene, Plantationocene, Chthulucene: Making Kin. Environmental Humanities (6): 159-165. DOI: https://doi.org/10.1215/22011919-3615934

Haraway, Donna (2016): Staying with the Trouble. Making Kin in the Chthulucene. Durham - London: Duke University Press.

Heckenberger, Michael J., J. Christian Russell, Joshua R. Toney és Morgan J. Schmidt (2007): The Legacy of Cultural Landscapes in the Brazilian Amazon: Implications for Biodiversity. Philosophical Transactions of the Royal Society B, Biological Sciences (362): 197-208. DOI: https://doi.org/10.1098/rstb.2006.1979

Holbraad, Martin és Morten Axel Pedersen (2017): The Ontological Turn. An Anthropological Exposition. Cambridge: Cambridge University Press.

Horton, Robin (1993): African Traditional Thought and Western Science. In Robin Hurton: Patterns of Thought in Africa and the West: Essays on Magic, Religion and Science. Cambridge: Cambridge University Press, 197-258. DOI: https://doi.org/10.1017/CBO9781139166232.008

Ingold, Tim (1992): Editorial. Man, New Series 27(4): 693-696.

Ingold, Tim (2018): Anthropology, Why It Matters. London: Polity Press.

Jupiter, Stacy (2017): Culture, Kastom and Conservation in Melanesia: What Happens When Worldviews Collide? Pacific Conservation Biology 23(2): 139-145. DOI: https://doi.org/10.1071/PC16031

Kohn, Eduardo (2015): Anthropology of Ontologies. Annual Review of Anthropology (44): 311-327. DOI: https:// doi.org/10.1146/annurev-anthro-102214-014127

Kohn, Eduardo (2013): How Forests Think. Toward an Anthropology Beyond the Human. Berkeley: University of California Press.

Kolodesnikov, Sergei (2000): The Person in the Traditional Yakut [Sakha] Worldview. A General Formulation of the Question. Anthropology \& Archeology of Eurasia 39(1): 42-79. DOI: https://doi.org/10.2753/AAE10611959390142

Ksenofontov Stanislav, Backhaus Norman és Gabriela Schaepman-Strub (2017): “To Fish or Not to Fish?” Fishing Communities of Arctic Yakutia in the Face of Environmental Change and Political Transformations. Polar Record 53(3): 289-303. DOI: https://doi.org/10.1017/S0032247417000134

Ksenofontov Stanislav, Backhaus Norman és Gabriela Schaepman-Strub (2018): There are New Species: Indigenous Knowledge of Biodiversity Change in Arctic Yakutia. Polar Geography 42(1): 34-57. DOI: https://doi.org/10.10 80/1088937X.2018.1547326 
Latour, Bruno (2013): Facing Gaia: Eight Lectures on the New Climatic Regime. London: Polity.

Lipschutz, Ronnie D. és Doreen Stabinsky (2019): Environmental Politics for a Changing World: Power, Perspectives, and Practice. Lanham - Boulder - New York - London: Rowman \& Littlefield.

Marohasy, Jennifer (szerk.) (2017): Climate Change: The Facts 2017. Victoria: Institute of Public Affairs.

Mészáros, Csaba (2012a): The Alaas: the Interplay Between Environment and Sakhas in Central-Yakutia. Halle: Max Planck Institute for Social Anthropology. (Max Planck Institute for Social Anthropology Working Papers 137.).

Mészáros Csaba (2012b): A környezetérzékelés változásai Szibériában az állami modernizációs törekvések tükrében. Jakutia példája. Ethno-Lore (29): 35-61.

Mészáros, Csaba (2012c): The Alaas: Cattle Economy and Environmental Perception of Sedentary Sakhas in Central Yakutia. Sibirica, Journal of Siberian Studies 11(2): 1-34. DOI: https://doi.org/10.3167/sib.2012.110202

Mészáros Csaba (2013): Tekintély és bizalom. Kultúra és társadalom két szibériai faluközösségben. Budapest: L'Harmattan - PTE Néprajz-Kulturális Antropológia Tanszék.

Mészáros Csaba (2016a): A tavak és az emberek kapcsolata. Az animizmus jelensége Jakutiában. Ethnographia 127(3): 391-411.

Mészáros, Csaba (2016b): Variable Husbandry and Changing Climate: Cattle Breeding and Permafrost Soil in Yakuta. Acta Ethnographica Hungarica 61(1): 35-57. DOI: https://doi.org/10.1556/022.2016.61.1.2

Mészáros, Csaba (2019): Multiplicity of Ontologies. Lakes and Humans in Siberia. Philosophy of Social Sciences 50(3). (megjelenés alatt).

Moore, Amelia (2015): Anthropocene Anthropology: Reconceptualizing Contemporary Global Change. Journal of the Royal Anthropological Institute (N.S.) 22(1): 27-46. DOI: https://doi.org/10.1111/1467-9655.12332

Moore, Jason W. (2016): Introduction. Anthropocene or Capitalocene? Nature, History, and the Crisis of Capitalism. In Anthropocene or Capitalocene? Nature, History, and the Crisis of Capitalism. Jason W. Moore (szerk.). Oakland: Kairos - PM Press, 1-10.

Nadasdy, Paul (1999): The Politics of TEK: Power and the 'Integration' of Knowledge. Arctic Anthropology 36(1-2): $1-18$.

Pratt, Marie-Louis (2017): Coda: Concept and Chronotope. In Arts of Living on a Damaged Planet Ghosts and Monsters of the Anthropocene. Anna Tsing, Heather Swanson, Elaine Gan és Nils Bubandt (szerk). Minneapolis: University of Minnesota Press, 169-176.

Prokop'eva, A. N. (2015): Alaas kak element sakral'nogo landshafta v kul'ture sovremennyh jakutov. Teorija i praktika obshhestvennogo razvitija (3): 138-142.

Protapopova, N. I. (2002): Ed'ii Dora. D’okuuskaj: Bichik.

Ruru, Jacinta, Phil B. O’Lyver, Scott Nigel és Deborah Edmunds (2017): Reversing the Decline in New Zealand's Biodiversity. Empowering Maori within Reformed Conservation Law. Policy Quarterly 13(2): 65-71. DOI: https://doi.org/10.26686/pq.v13i2.4657

Sivadó Ákos (2015): The Shape of Things to Come? Reflections on the Ontological Turn in Anthropology. Philosophy of the Social Sciences 45(1): 83-99. DOI: https://doi.org/10.1177/0048393114524830

Slepcov-Sylyk, N. I. (2013): Dyhanie vechnoj merzloty. Jakutsk: Bichik.

Smart, Alan és Josephine Smart (2017): Posthumanism: Anthropological Insights. Toronto: University of Toronto Press.

Sponsel, Leslie E. (2017): Spiritual Ecology, Sacred Places, and Biodiversity Conservation. In Routledge Handbook of Environmental Anthropology. Helen Kopnina és Eleanor Shoreman-Ouimet (szerk.). London: Routledge, 132-143.

Spyer, Patricia (2011): What Ends with the End of Anthropology? In The End of Anthropology? Holger Jebens és Karl-Heinz Kohl (szerk.). Wantage: Sean Kingston, 61-80.

Steffen, Will, Peter Crutzen és John R. McNeill (2007): The Anthropocene: are Humans now Overwhelming the Great Forces of Nature? Ambio 36(8): 614-621. DOI: https://doi.org/10.1579/0044-7447(2007)36[614:TAAHN O]2.0.CO;2

Sterling, Eleanor, Filardi, C.; Toomey, A.; Sigouin, A.; Betley, E.; Gazit, N.; Newell, J.; Albert, S.; Alvira, D.; Bergamini, N.; Blair, M.; Boseto, D.; Burrows, K.; Bynum, N.; Caillon, S.; Caselle, J.E.; Claudet, J.; Cullman, G.; Dacks, R.; Eyzaguirre, P.; Gray, S.; Herrera, J.; Kenilorea, P.; Kinney, K.; Kurashima, N.; Macey, S.; Malone, C.; Mauli, S.; McCarter, J.; McMillen, H.; Pascua, P.; Pikacha, P.; Porzeccanski, A.L.; de Robert, P.; Salpeteur, M.; Sirikolo, M.; Stege, M.H.; Stege, K.; Ticktin, T.; Vave, R.; Wali, A.; West, P.; Winter, K.B. és Jupiter, S.D. (2017): Biocultural Approaches to Well-being and Sustainability Indicators Across Scales. Nature Ecology \& Evolution (1): 1798-1806. DOI: https://doi.org/10.1038/s41559-017-0349-6

Steward, Julian (1955): Theory of Culture Change. The Methodology of Multilinear Evolution. Urbana: University of Illinois Press. 
Stilgoe, Jack (2015): Experiment Earth: Responsible Innovation in Geoengineering. London: Routledge.

Tabyrynova, L. Ju (2010): Tradicionno-kul'turnoe otnoshenie k prirodnoj vodnoj srede v uslovijah globalizacii. Sistema cennostej sovremennogo obshchestva (15): 194-198.

Takada, Jun, Valery E. Stepanov, Daniel P. Yefremov, Takahiro Shintani, Akitane Akiyama, Masami Fukuda és Masaharu Hoshi (1999): Radiological States around the Kraton - 4 Underground Nuclear Explosion Site in Sakha. Journal of Radiation Research 40(3): 223-228. PMID: 10641484.

Takakura, Hiroki (2015): Arctic Pastoralist Sakha. Ethnography of Evolution and Microadaptation in Siberia. Melbourne: Trans Pacific Press.

Tsing, Anna (2015): The Mushroom at the End of the World. Princeton: Princeton University Press.

Vakhtin Nikolaj (2001): Franz Boas and the Shaping of the Jesup Research in Siberia. In Gateways: Exploring the Legacy of the Jesup North Pacific Expedition, 1897-1902. Igor Krupnik és William W. Fitzhugh (szerk.). Washington D. C.: Arctic Studies Center and National Museum of Natural History and Smithsonian Institution, 71-89.

Vitebsky, Piers és Anatoly Alekseyev (2015): Siberia. Annual Review of Anthropology (44): 439-455. DOI: https:// doi.org/10.1146/annurev-anthro-092412-155546

Viveiros de Castro, Eduardo (1998): Cosmological Deixis and Ameridian Perspectivism. Journal of the Royal Anthropological Institute 4(3): 469-488. DOI: https://doi.org/10.2307/3034157

Viveiros de Castro, Eduardo (2004): Exchanging Perspectives: The Transformation of Objects into Subjects in Amerindian Cosmologies. Common Knowledge 10(3):463-484.DOI: https://doi.org/10.1215/0961754X-10-3-463

Viveiros de Castro, Eduardo (2013): The Relative Native. HAU: Journal of Ethnographic Theory 3(3): 473-502. DOI: https://doi.org/10.14318/hau3.3.032

West, Paige (2005): Translation, Value, and Space: Theorizing an Ethnographic and Engaged Environmental Anthropology. American Anthropologist (107): 632-642. DOI: https://doi.org/10.7916/D8MW2NR2

Willerslev, Rane, Piers Vitebsky és Anatolii Alekseyev (2015): Sacrifice as the Ideal Hunt: a Cosmological Explanation for the Origin of Reindeer Domestication. The Journal of the Royal Anthropological Institute 21(1): 1-23. DOI: https://doi.org/10.1111/1467-9655.12142

Yamada, Takako (2006): Nature as the Quintessence of Sakha Shamanism Revived. Human Evolution (21): 211-223.

A tanulmány megjelenését az SNN 126230-as számú Védett területek a szlovén-magyar határ mentén. Az együttmüködés és a fenntartható fejlödés kihívásai nevü kutatási program támogatta.

\section{Mészáros Csaba}

Etnológus, MTA BTK Néprajztudományi Intézet (Budapest) 